\title{
P04-35. Neutralisation activity in a geographically diverse East London cohort of HIV-I infected patients
}

\section{H Dreja*1, E O'Sullivan ${ }^{1}$, C Pade ${ }^{1}$, K Aubin ${ }^{1}$, A Isaksen ${ }^{2}$, C D'Souza ${ }^{2}$, J Hand ${ }^{2}$, C Orkin ${ }^{2}$, W Leber ${ }^{3}$, J Anderson ${ }^{3}$ and Á McKnight ${ }^{1}$}

Address: ${ }^{1}$ Centre of Infectious Diseases, Barts and The London, Queen Mary's School of Medicine and Dentistry, London, UK, ${ }^{2}$ Grahame Hayton Unit, The Royal London Hospital, London, UK and ${ }^{3}$ Homerton University Hospital, London, UK

* Corresponding author

from AIDS Vaccine 2009

Paris, France. 19-22 October 2009

Published: 22 October 2009

Retrovirology 2009, 6(Suppl 3):P63 doi:10.1186/1742-4690-6-S3-P63

This abstract is available from: http://www.retrovirology.com/content/6/S3/P63

C 2009 Dreja et al; licensee BioMed Central Ltd.

\section{Background}

East London has a diverse population profile, where many of the inhabitants come from abroad. Consequently, they harbour viruses from the farthest corners of the globe, which partly reflect the worldwide HIV-1 epidemic. We have looked at antibody responses in this cohort and tried to establish the relationship of neutralising antibodies to viruses from the same versus different clades.

\section{Methods}

To date, $>330$ patients have been recruited. Neutralisation activity in plasma extracted from the treatment-naive patients was determined on TzmBl cells with a panel of 11 viruses, representing 6 different clades.

\section{Results}

Overall, the plasmas do not differ much between the groups in terms of virus neutralisation. However, we did find that clade $\mathrm{C}$ infected individuals neutralised the tested clade $\mathrm{C}$ viruses significantly better than the clade $\mathrm{B}$ patients. Moreover, following titrations clade $\mathrm{C}$ plasmas neutralised a CRF02_AG virus better than the AG samples.

\section{Conclusion}

Neutralisation activities appeared relatively sporadic and independent of genetic clades, although we suggest that clade $\mathrm{C}$ exposure may induce a neutralising humoral response to help control clade C and CRF02_AG challenge. 